\title{
Effective microbiocidal activity of Ocimum sanctum L. and Ocimum gratissimum
}

\section{L. extracts}

\author{
Nasrin Rahman, Basanta Kumar Borah», Tankeswar Nath, Swapnali Hazarika*, Sushil Singh and Akhil Ranjan Baruah \\ Department of Agricultural Biotechnology, Assam Agricultural University, Jorhat-785013, Assam, India \\ *Chemical Engineering Group, CSIR-North East Institute of Science and Technology, Jorhat-785006, Assam, India
}

\section{Article Info}

Article history

Received 3 August 2021

Revised 20 September 2021

Accepted 21 September 2021

Published Online 30 December 2021

Keywords
Ocimum
Basil
Agar well-diffusion
Antibacterial activity
Antifungal activity
HPLC fingerprinting

\begin{abstract}
Innovation of effective antimicrobial agents in terms of resistance against various pathogenic microorganisms is a universal challenge for the pathologists and researchers, leading to improvement of innovative technologies that have great potential and efficacy. With this intention, we investigated and compared the antimicrobial activities of leaf extracts of Ocimum sanctum L. and Ocimum gratissimum L. against few bacteria, such as Escherichia coli, Agrobacterium tumefaciens and Bacillus megaterium, and fungi such as Fusarium oxysporum and F. solani. Methanol, petroleum ether, nhexane as well as water were used to prepare the extracts; the antimicrobial activities were tested using the well-diffusion method. As expected, irrespective of the solvent, the highest concentration (100\%) of the extract generally showed the highest efficacy with the largest zones of inhibition of the three bacterial and two fungal species. Among the solvents, overall, the methanolic extract was the most effective (showing the largest zones of inhibition) against bacteria; but the solvents did not show any difference in their activity between the two fungal species. Meanwhile, the most susceptible bacterial species against both the species of tulsi was A. tumefaciens, and the most susceptible fungal species was $F$. oxysporum. The extracts of $O$. gratissimum showed relatively higher antimicrobial activity against both bacteria and fungi; this finding correlated with the higher vigour, stronger aroma and higher eugenol content of this species of tulsi. HPLC-fingerprinting of them showed different patterns that correlated with their antimicrobial activities.
\end{abstract}

\section{Introduction}

Ocimum is a versatile aromatic genus and is considered as the most sacred plant in the Indian subcontinent. The plant also contains economically important essential oils, and is one of the most important medicinal herbs used in several traditional medicinal systems. The Ocimum species, popular as Basil, is one of the largest genera of the Lamiaceae family (Sajjadi, 2006) with nearly 160 species. It is native to the tropical and subtropical Asia, Africa, and Central and South America (Darrah, 1974). India is home to nine and the North East India to four species of the plant (Kalita and Khan, 2013). Because of the great diversity of the genus, its members are placed under two categories, viz., the Basilicum and the Sanctum group. The Basilicum group includes $O$. canum, $O$. basilicum, $O$. americanum and $O$. kilimandsacharium; and the Sanctum group includes $O$. sanctum, $O$. gratissimum, $O$. viride, $O$. sauve and $O$. micranthum. Commonly known medicinal species include $O$. sanctum (Krishna tulsi), O. gratissimum (Ram tulsi), O. canum (Dulal tulsi), O. bascilicum (Ban tulsi), O. kilimandsachricum, O. americanum, O. camphora and O. micranthum (Kalita and Khan, 2013; Atal and Kapur, 1989). In Assam, two types of Ocimum are mostly cultivated;

Corresponding author: Dr. Basanta Kumar Borah Assistant Professor, Department of Agricultural Biotechnology, Assam Agricultural University, Jorhat-785013, Assam, India

E-mail: basanta.k.borah@aau.ac.in

Tel.: +91-8011050299

Copyright (c) 2021 Ukaaz Publications. All rights reserved.

Email: ukaaz@yahoo.com; Website: www.ukaazpublications.com the Ram tulsi (O. gratissimum) possessing green leaves, and the Krishna tulsi $(O$. sanctum) bearing purple leaves.

The genus, Ocimum, is an important source of medicine, and contains a wide range of essential oils and other products. The essential oils are rich in phenolics, and are responsible for its aroma and biological activity (Sajjadi, 2006). Eugenol (1-hydroxy-2-methoxy-4-allylbenzene) is an active constituent present in $O$. sanctum which largely controls the therapeutic potentials of the plant (Singh and Kumar, 2010). O. gratissimum exhibited antifungal activity against dermatophytes, imperfect filamentous fungi and pathogenic yeasts (Koba $e t$ al., 2009), and also against Aspergillus repens, Curvularia lunata and Fusarium moniliforme (Amadi et al., 2010). The medicinal properties exhibited by the Ocimum spp. include adaptogenic, metabolic, antibacterial, antifungal, immunomodulatory, analgesic, antiulcer, anti-inflammatory, antioxidant, antistress, antiarthritic, antiasthmatic, radioprotective, antioxidant, antifertility, anticancer, anticonvulsant, antidiabetic, antihyperlipidemic, memory enhancer and neuroprotective activity (Kadian and Parle, 2012; Jamshidi and Cohen, 2017). Methanolic extracts of $O$. sanctum revealed its antibacterial activity against pathogens such as Enterococcus faecalis, Enterobacter cloacae, Escherichia coli, Proteus vulgaris, Klebsiella pneumoniae, Staphylococcus aureus and S. saprophyticus (Tantry et al., 2016). Hexane and ethanolic extract of $O$. sanctum also showed antimicrobial activity against $S$. aureus, E. coli and Klebsiella spp. (Bansavatar et al., 2015). Camphor, eucalyptol and eugenol present in O. tenuiflorum show antimicrobial activity against $S$. aureus, 
E. coli and Pseudomonas aeruginosa (Yamani et al., 2016). Not only the organic, but aqueous extract of $O$. sanctum also showed antifungal properties against A. niger, Rizopous, Cladpsporium, Curvularia lunata, and Candida spp. (Khan et al., 2010).

Even today, $80 \%$ of 122 drugs derived from plants were related to their ethnopharmacological uses (Fabricant and Farnsworth, 2001). Tulsi beings an ethnically important medicinal plant, it is essential to understand the useful properties of its compounds and their modes of action for their purposing and repurposing. The plant has been reported to be non-toxic and safe in clinical rat trials (Gautam and Goel, 2014); none of its compounds was found to have any adverse effect on human health (Jamshidi and Cohen, 2016).

Although, some works have been done on antimicrobial activities of tulsi, there is almost no report of comparison of antimicrobial activity among its species, and solvent extracts. Therefore, we aimed this investigation to screen antimicrobial activity of the leaf extracts of $O$. sanctum and $O$. gratissimum against few common microbes. A comparative HPLC fingerprinting also had been done for relative quantification of their bioactive compounds.

\section{Materials and Methods}

\subsection{Materials}

The following chemicals and reagents were used in this study: (i) Methanol (for extraction; AR grade; Sigma Aldrich, USA), (ii) Petroleum ether (AR grade; Sigma Aldrich, USA), (iii) n-hexane (AR grade; Sigma Aldrich, USA), (iv) Dimethyl sulphoxide (DMSO; AR grade; Sigma Aldrich, USA), (v) LB (Miller; microbiology grade; Sigma Aldrich, USA), (vi) LB Agar (Miller; microbiology grade; Sigma Aldrich, USA), (vii) Nutrient Agar (NA; microbiology grade; Sigma Aldrich, USA), (viii) Streptomycin sulfate (USP Grade; Sigma Aldrich, USA), (ix) Cyclohexamide (microbiology grade; Sigma-Aldrich, USA), and (x) Formic acid (LiChropur ${ }^{\mathrm{TM}}$; Sigma Aldrich, USA), (xi) Methanol (gradient grade; Sigma Aldrich, USA), and (xii) Potato dextrose agar (PDA; Sigma Aldrich, USA).

\subsection{Collection of plant materials}

The seedlings of Ocimum species were collected from the medicinal plant collection of the Department of Agronomy, Assam Agricultural University, India. The plants were grown in sandy loam soil enriched with organic matters and maintained in net-house. For extraction, the leaves of $O$. sanctum and $O$. gratissimum were washed thoroughly, dried under shade and ground into fine powder using a blender passing through $0.33 \mathrm{~mm}$ sieve.

\subsection{Preparation of leaf extracts}

Thirty-five gram of leaf powder was put in a thimble, which was placed in the Soxhlet extractor. $350 \mathrm{ml}$ of each of methanol, $\mathrm{n}$-hexane, petroleum ether and water were used to extract for about $6 \mathrm{~h}$ until no single drop of solvent left the residues. The extracted solutes were concentrated into $1 / 10^{\text {th }}$ volume in a rotary evaporator. The final extract was stored at $4^{\circ} \mathrm{C}$. The extracts in methanol, petroleum ether and n-hexane were dissolved in DMSO to prepare different concentrations $(25 \%, 50 \%, 75 \%$ and $100 \%)$ to assess their antimicrobial activity.

\subsection{Screening of antibacterial activity by agar well-diffusion}

Antibacterial activities of the extracts were evaluated according to the method of Bauer et al. (1966). From single colony, $10 \mathrm{ml}$ of culture of each bacterium was obtained at $200 \mathrm{rpm}$ in a mechanical shaker incubator; cultures were raised $28^{\circ} \mathrm{C}-30^{\circ} \mathrm{C}$ for Agrobacterium tumefaciens and Bacillus megaterium, and $37^{\circ} \mathrm{C}$ for Escherichia coli. Incubation was done for $12 \mathrm{~h}$ for B. megaterium and E. coli; and for $48 \mathrm{~h}$ for $A$. tumefaciens. From these broths, $500 \mu \mathrm{l}$ of bacterial cultures were transferred to LB Agar and NA plates, and were spread evenly. Five wells were made on each plate: three of them for different concentrations (viz., 25\%, 50\%, 75\% and 100\%) of tulsi extracts, one for positive control (streptomycin) and one for negative control (DMSO). The wells were filled with $50 \mu \mathrm{l}$ of respective extract assigned for it. The plates were incubated at similar conditions without revolution.

\subsection{Screening of antifungal activity by agar well-diffusion}

The fungi were cultured from pure-culture plates on PDA media and were incubated at $30^{\circ} \mathrm{C}$ for 3 days. Fresh plates were inoculated on one edge and were incubated at $30^{\circ} \mathrm{C}$ for 2 days. Wells were plunged in the plates where $50 \mu \mathrm{l}$ each of the above four concentrations of extracts were added; the plates were again incubated at the same temperature for 3 days. The positive control was cyclohexamide, a highly effective antibiotic used against fungi, and the negative control was DMSO. The plates were observed everyday for 6 days.

\subsection{Scoring of zones of inhibition}

After incubation, clear zones of different sizes were observed around the wells containing the various concentrations of tulsi extracts and the positive control. The diameter of the inhibition zones, as mentioned in the table legends, was measured with rulers in millimeter $(\mathrm{mm})$. The screening was repeated three times for each bacterium, and corresponding values of zones of inhibition for each concentration of the tulsi extract, and for each of the bacterial and fungal species were averaged. The values thus obtained were compared with the different concentrations of the same extract, same concentration of different extracts and with the positive and the negative controls.

\subsection{HPLC fingerprinting of Ocimum extract}

The HPLC analyses of the methanol, n-hexane and aqueous leaf extracts of $O$. sanctum and $O$. gratissimum were done in the UHPLC model Dionex (Thermo Fisher, USA) system. The system was equipped with $\mathrm{C}_{18}$ column $(5 \mu \mathrm{m} ; 120 \AA$; $4.6 \times 250 \mathrm{~mm})$ in CSIRNorth East Institute of Science and Technology, Jorhat, India. The sample volumes used for injection into the column was $20 \mu \mathrm{l}$, and the flow rate was $0.50 \mathrm{ml} / \mathrm{min}$. The mobile phase used in this system comprised of $1: 4$ ratios of $0.1 \%$ formic acid and methanol. The detection of the eluting compounds was carried out at $230 \mathrm{~nm}$ at run time of $30 \mathrm{~min}$. The HPLC parameters such as robustness, accuracy, limit of detection (LOD), linearity, etc., were calculated according to ICH (2005) and Fuster et al. (2015). For robustness, a given solution was evaluated in sextuplicate submitted to different conditions (flow temperature, composition). A relative standard deviation value $<5 \%$, with accuracy of $\pm 5 \%$ was considered robust. Intra-assay variation was checked by triplication of analytical curve and evaluation of the midpoint six times on the same day. The LOD was calculated based on the standard deviation and slope of the calibration curve by 3.3 $\mathrm{SD} /$ Sample. 


\subsection{Data analysis}

The experimental data entry was done in MS Excel spreadsheet for further analysis. Various means with standard errors, analysis of variance (ANOVA), followed by Tukey multiple comparison test were performed using MS Excel and Graph Pad PRISM 8 to compare the level of efficacy of different treatment regimes. The data were analysed to understand the effects of various concentrations of the tulsi extracts and to test whether the means for zones of inhibition differ significantly among the three bacterial species. To test whether or not to reject the null hypothesis when it is true, levels of significance used were: $5 \%(<0.05), 1 \%(<0.01), 0.1 \%(<0.001)$ and $0.001 \%(<0.0001)$ probability (p-value), respectively. The data were of laboratory origin, and utmost care was taken to ensure uniform environmental conditions (simulated) for each event. Still, three replications were kept for each data point, and means and standard errors were well considered for further analysis.

\section{Results}

\subsection{Antibacterial activity of Ocimum extracts}

The antibacterial activities of the tulsi extracts were evaluated against three common bacterial strains, E. coli, A. tumefaciens and B. megaterium. The presence or absence of the zone of inhibition indicates susceptibility or resistance, respectively, of the particular bacteria against the metabolite (s) present in the specific solvent extract of Ocimum. The results of the relevant assays are presented in Table 1 and Table 2 and in Figure 1. It was clear that irrespective of the solvent systems used, with the increase in the concentrations of the extract, the diameter/size of the zones of inhibition increased. The zone of inhibition in case of positive control (streptomycin) was considerably larger compared to all the solvent extracts, as expected. No zone was observed in the negative control.

Table 1: Zone of inhibition of $O$. sanctum at different concentrations against test bacterial species [diameter of the zone of inhibition is shown in $\mathrm{mm}$ (Mean $\pm \mathrm{SE}$ )]. The highest values are indicated by blue bold font for each bacterial species

\begin{tabular}{|c|c|c|c|c|c|c|c|c|c|c|c|c|c|}
\hline \multirow[t]{2}{*}{ Sl.No. } & \multirow[t]{2}{*}{ Microorganisms } & \multicolumn{4}{|c|}{ Methanol extract } & \multicolumn{4}{|c|}{ Petroleum ether extract } & \multicolumn{4}{|c|}{ n-hexane extract } \\
\hline & & $25 \%$ & $50 \%$ & $75 \%$ & $100 \%$ & $25 \%$ & $50 \%$ & $75 \%$ & $100 \%$ & $25 \%$ & $50 \%$ & $75 \%$ & $100 \%$ \\
\hline 1. & Escherichia coli & $\begin{array}{c}9.33 \pm \\
0.33\end{array}$ & $\begin{array}{c}11.33 \pm \\
0.33\end{array}$ & $\begin{array}{c}11.67 \pm \\
0.33\end{array}$ & $\begin{array}{l}13 \pm \\
0.57\end{array}$ & $\begin{array}{c}9.33 \pm \\
0.67\end{array}$ & $\begin{array}{c}9.67 \pm \\
0.33\end{array}$ & $\begin{array}{c}10.67 \pm \\
0.33\end{array}$ & 12 & $\begin{array}{c}6.83 \pm \\
0.44\end{array}$ & $\begin{array}{c}8.83 \pm \\
0.44\end{array}$ & $\begin{array}{c}9.83 \pm \\
0.44\end{array}$ & $\begin{array}{l}11 \pm \\
0.57\end{array}$ \\
\hline 2 & Bacillus megaterium & $\begin{array}{c}11.33 \pm \\
0.33\end{array}$ & $\begin{array}{c}11.83 \pm \\
0.16\end{array}$ & $\begin{array}{c}12.83 \pm \\
0.167\end{array}$ & $\begin{array}{c}13.83 \pm \\
0.167\end{array}$ & $\begin{array}{c}10 \pm \\
0.30\end{array}$ & $\begin{array}{c}10.33 \pm \\
0.33\end{array}$ & $\begin{array}{c}10.67 \pm \\
0.67\end{array}$ & $\begin{array}{l}13 \pm \\
0.57\end{array}$ & $\begin{array}{c}6.67 \pm \\
0.33\end{array}$ & $\begin{array}{c}7.33 \pm \\
0.33\end{array}$ & $\begin{array}{c}7.67 \pm \\
0.33\end{array}$ & $\begin{array}{c}10.67 \pm \\
0.33\end{array}$ \\
\hline 3 & $\begin{array}{l}\text { Agrobacterium } \\
\text { tumefaciens }\end{array}$ & $\begin{array}{c}12 \pm \\
2\end{array}$ & $\begin{array}{l}14 \pm \\
0.57\end{array}$ & $\begin{array}{c}17.33 \pm \\
0.67\end{array}$ & $\begin{array}{c}18.67 \pm \\
0.67\end{array}$ & $\begin{array}{c}9 \pm \\
0.57\end{array}$ & $\begin{array}{l}11 \pm \\
0.57\end{array}$ & $\begin{array}{c}11.67 \pm \\
0.33\end{array}$ & $\begin{array}{l}12 \pm \\
0.57\end{array}$ & $\begin{array}{c}9.33 \pm \\
0.33\end{array}$ & $\begin{array}{l}12 \pm \\
0.57\end{array}$ & $\begin{array}{c}12.67 \pm \\
1.45\end{array}$ & $\begin{array}{c}15.67 \pm \\
1.76\end{array}$ \\
\hline
\end{tabular}

Table 2: Zone of inhibition by $O$. gratissimum at different concentrations against test bacterial species [diameter of the zone of inhibition is shown in $\mathrm{mm}$ (Mean $\pm \mathrm{SE}$ )]. The highest values are indicated by blue bold font for each bacterial species

\begin{tabular}{|c|c|c|c|c|c|c|c|c|c|c|c|c|c|}
\hline \multirow{2}{*}{$\begin{array}{l}\text { Sl. } \\
\text { No. }\end{array}$} & \multirow[t]{2}{*}{ Microorganisms } & \multicolumn{4}{|c|}{ Methanol extract } & \multicolumn{4}{|c|}{ Petroleum ether extract } & \multicolumn{4}{|c|}{ n-hexane extract } \\
\hline & & $25 \%$ & $\mathbf{5 0 \%}$ & $75 \%$ & $100 \%$ & $25 \%$ & $\mathbf{5 0 \%}$ & $75 \%$ & $100 \%$ & $25 \%$ & $50 \%$ & $75 \%$ & $100 \%$ \\
\hline 1. & Escherichia coli & $\begin{array}{c}10.33 \pm \\
0.33\end{array}$ & $\begin{array}{l}12 \pm \\
0.57\end{array}$ & $\begin{array}{c}13.33 \pm \\
0.88\end{array}$ & $\begin{array}{c}15.67 \\
1.76\end{array}$ & $\begin{array}{c}9 \pm \\
0.57\end{array}$ & 10 & $\begin{array}{l}11 \pm \\
0.57\end{array}$ & $\begin{array}{c}2.67 \pm \\
1.20\end{array}$ & $\begin{array}{l}11 \pm \\
0.57\end{array}$ & $\begin{array}{c}11.33 \pm \\
0.33\end{array}$ & $\begin{array}{l}12 \pm \\
0.57\end{array}$ & $\begin{array}{c}12.67 \pm \\
0.33\end{array}$ \\
\hline 2 . & $\begin{array}{l}\text { Bacillus } \\
\text { megaterium }\end{array}$ & $\begin{array}{c}8.33 \pm \\
0.33\end{array}$ & $\begin{array}{c}8.67 \pm \\
0.67\end{array}$ & $\begin{array}{c}9.67 \pm \\
0.33\end{array}$ & $\begin{array}{c}13.33 \pm \\
0.88\end{array}$ & 10 & $\begin{array}{c}11.67 \pm \\
0.67\end{array}$ & $\begin{array}{l}12 \pm \\
0.57\end{array}$ & $\begin{array}{l}2.33 \pm \\
0.33\end{array}$ & $\begin{array}{l}10 \pm \\
0.57\end{array}$ & $\begin{array}{c}10.67 \pm \\
0.33\end{array}$ & $\begin{array}{l}11 \pm \\
0.57\end{array}$ & $\begin{array}{c}11.16 \pm \\
0.167\end{array}$ \\
\hline 3 . & $\begin{array}{l}\text { Agrobacterium } \\
\text { tumefaciens }\end{array}$ & $\begin{array}{l}13 \pm \\
0.57\end{array}$ & $\begin{array}{c}14.33 \pm \\
1.20\end{array}$ & $\begin{array}{c}15.33 \pm \\
0.33\end{array}$ & $\begin{array}{l}20 \pm \\
0.57\end{array}$ & $\begin{array}{l}14 \pm \\
0.57\end{array}$ & $\begin{array}{l}16 \pm \\
0.57\end{array}$ & $\begin{array}{c}18.33 \pm \\
0.88\end{array}$ & $\begin{array}{c}8.67 \pm \\
0.88\end{array}$ & $\begin{array}{c}12.33 \pm \\
0.88\end{array}$ & $\begin{array}{c}13.67 \pm \\
0.33\end{array}$ & $\begin{array}{l}15 \pm \\
0.57\end{array}$ & $\begin{array}{l}19 \pm \\
0.57\end{array}$ \\
\hline
\end{tabular}

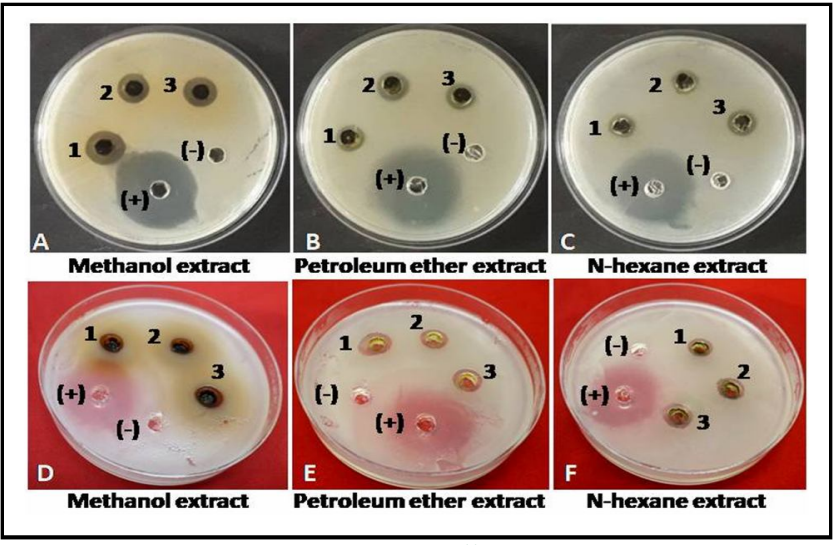

Figure 1: Zones of inhibition of Bacillus megaterium against $100 \%$ extracts of (A), (B), (C) O. gratissimum and (D), (E), (F) O. basilicum. 1, 2, 3: three replications; (+): positive control, (-) negative: control.
Activity of the methanolic extract of $O$. gratissimum was found higher over that of $O$. sanctum against $E$. coli and A. tumefaciens, except at $75 \%$ concentration, where the $O$. sanctum extract showed higher activity (inhibition zone with diameter $17.33 \pm 0.67 \mathrm{~mm}$ ) over $O$. gratissimum extract $(15.33 \pm 0.33 \mathrm{~mm})$ against the later. In case of $B$. megaterium; however, an almost opposite result was found, where activity (diameter of inhibition zones) of the methanolic extract of $O$. sanctum was higher over that of $O$. gratissimum in all the concentrations. However, the activity of petroleum ether extract of $O$. gratissimum was found higher over that of $O$. sanctum against A. tumefaciens at all the concentrations. In case of other two bacterial species, the petroleum ether extracts of both the tulsi species showed near-equal activity in all the concentrations tested. On the other hand, the n-hexane extract of $O$. gratissimum showed higher activity over that of $O$. sanctum against all the three bacterial species irrespective of their concentrations.

Considering the solvent system, irrespective of concentrations, the activity of the methanolic extracts for both the tulsi species was found to be the highest against all the three bacterial species followed 
by $n$-hexane and then by petroleum ether extract. Exception was found in A. tumefaciens, against whom almost equal activities were shown by the methanol and the n-hexane extracts. Among the three bacterial species, the A. tumefaciens showed the highest susceptibility to both the tulsi extracts at all the four concentrations in all the solvents tested.

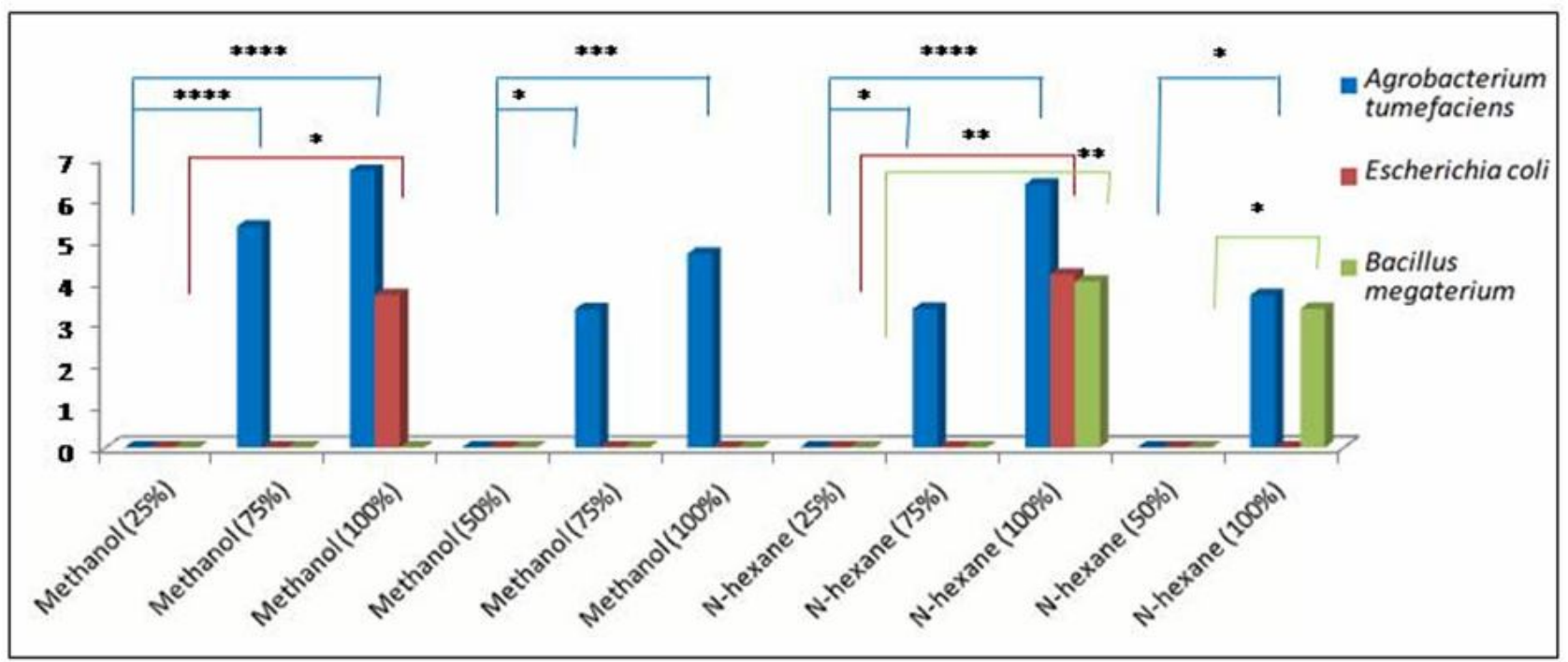

Figure 2: Tukey multiple comparison test for effects of various doses of treatments for individual extract showing significant difference of means for zone of inhibition (values in the Y-axis) among the three bacteria species. Doses of petroleum ether is not in the figure as it failed to show significant difference. *,**,***,*** indicate the level of significances at $p$-value $<0.05,<0.01,<0.001,<0.0001$, respectively.
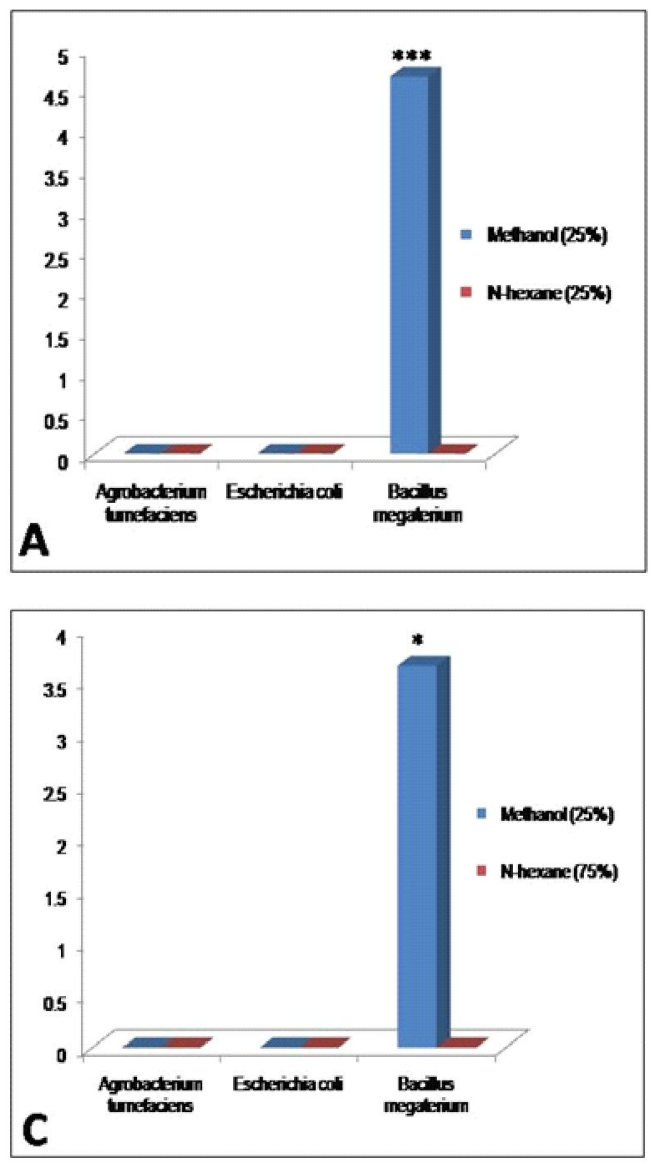
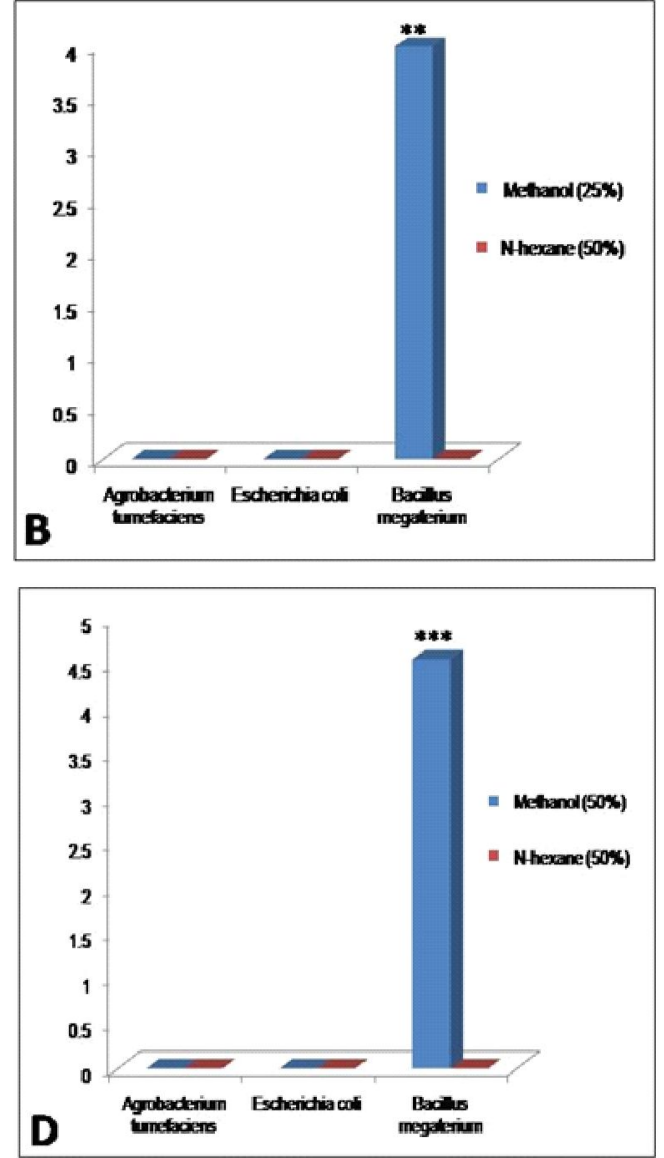

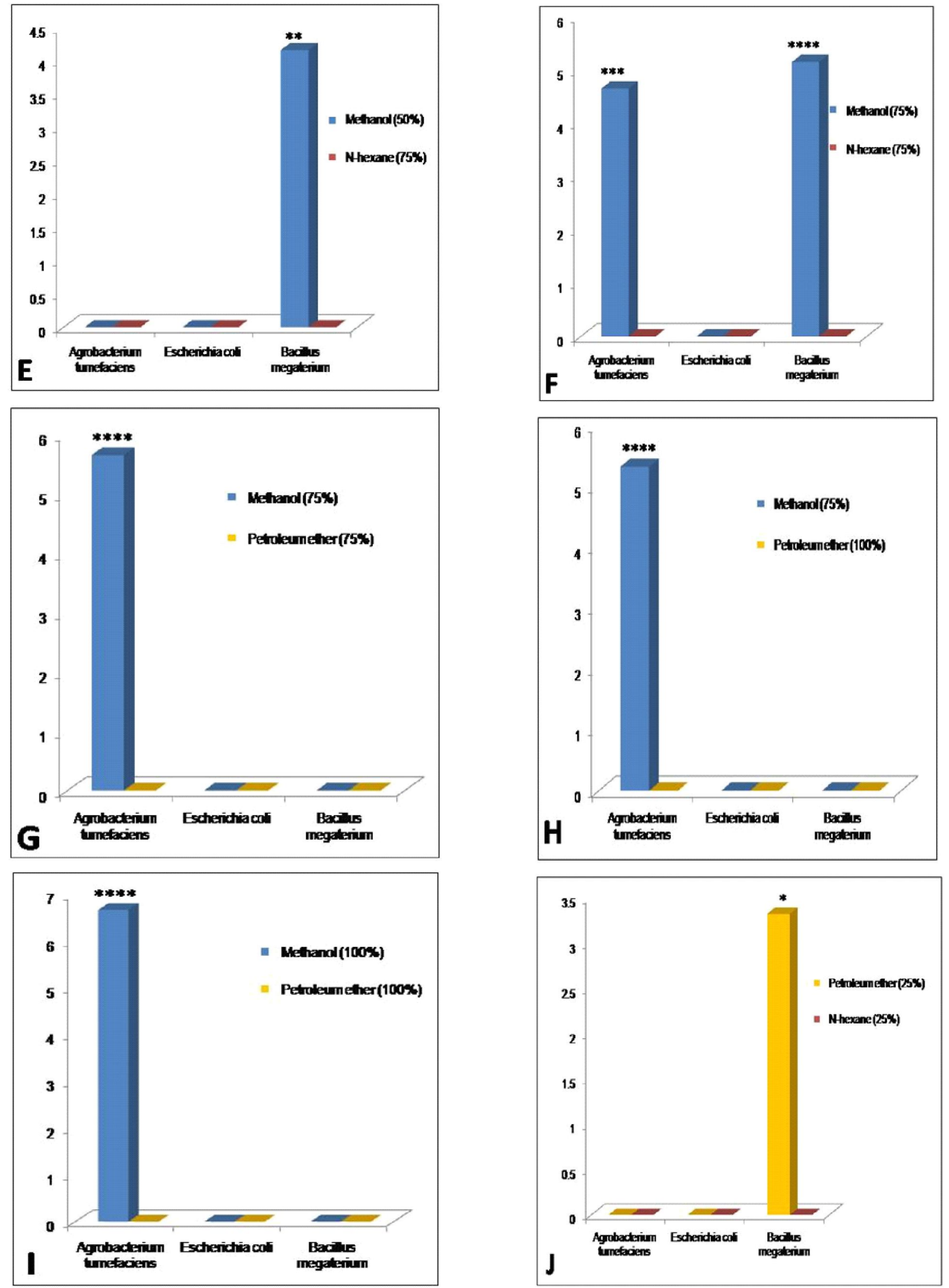


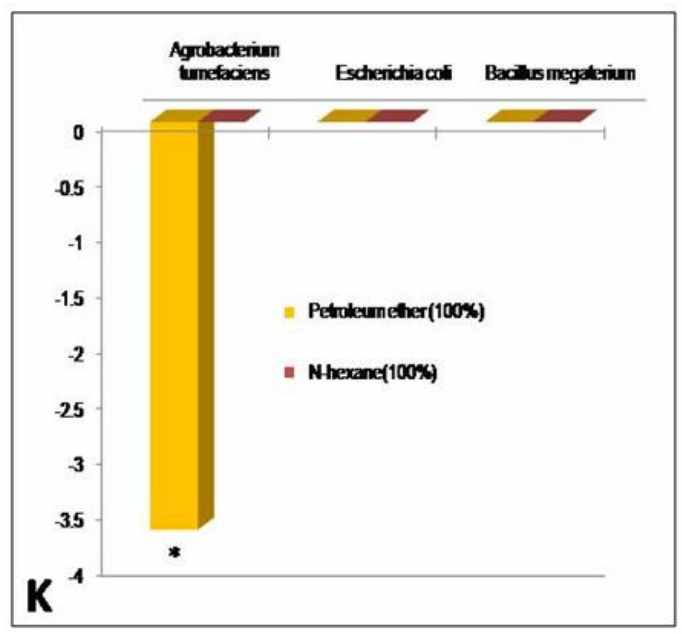

Figure 3: Comparative performance study of the three extracts as revealed by the significant mean differences for zones of inhibition (values in the Y-axis) in the bacteria species. *, **, ***,**** indicate the level of significances at $p$-value $<0.05,<0.01,<0.001,<0.0001$, respectively.

Between the two Ocimum species, relatively higher antibacterial activity was found in $O$. gratissimum (the largest zone of inhibition of diameter $20 \pm 0.57 \mathrm{~mm}$ in methanolic extract against $A$. tumefaciens) compared to $O$. sanctum (the largest zone of inhibition of diameter $18.67 \pm 0.67 \mathrm{~mm}$ in methanolic extract against A. tumefaciens). As expected, the highest concentration of the extract showed the maximum inhibition of bacterial growth. With respect to the solvent system used, we found that the methanol extract was the most

potent. Meanwhile, A. tumefaciens was the most vulnerable bacterial species to the extracts of both the species of tulsi.

Statistically, among the concentrations of the respective extract, any difference of $50 \%$ or above showed highly significant difference for two extracts, namely; methanol and n-hexane (Figure 2). Concentration difference below $50 \%$ for individual extract, difference was nearly non-existent. This indicated similar concentrations of different solvent-extracts had similar antibacterial activity. The effects of the three concentrations of methanol extract on two bacterial species were more prominent over $n$-hexane extract; all the bacterial species responded equally to the various doses of n-hexane (Figure 2). However, all the concentrations of petroleum ether extract tested could not show any significant difference for antibacterial activity between any two doses against the three bacterial species. As we applied Tukey multiple comparison tests to detect which out of these three extracts at specific concentration showed higher antibacterial activity; we compared the effects of specific concentration of one extract with the same or higher concentration of another extract. Although ${ }^{3} \mathrm{C}_{4}$ comparisons were carried out, the results showing significant difference for mean zones of inhibition only are presented in Figure 3. The antibacterial activity was significantly higher for methanol extract than that of $n$-hexane and petroleum ether extracts at equal doses of $25 \%, 50 \%, 75 \%$ and $100 \%$, respectively, indicating the efficacy of methanol extract over the other two extracts. Even the doses of methanol at $25 \%$ and $50 \%$ were superior over higher doses of $n$-hexane; the level of significance was, however, different. The same was observed for methanol 75\% and petroleum ether $100 \%$ concentrations. However, we could rarely detect any significant difference for antibacterial activity between petroleum ether and n-hexane. We tried with three different extracts with four doses out of which methanol was found to be relatively effective against the bacterial species studied.

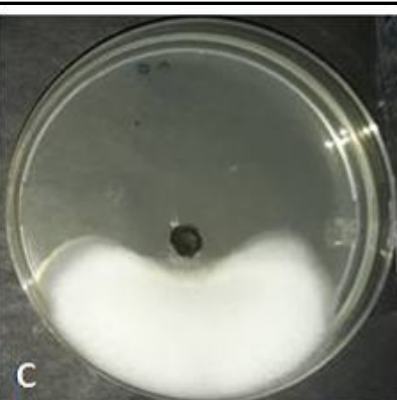

\section{B}

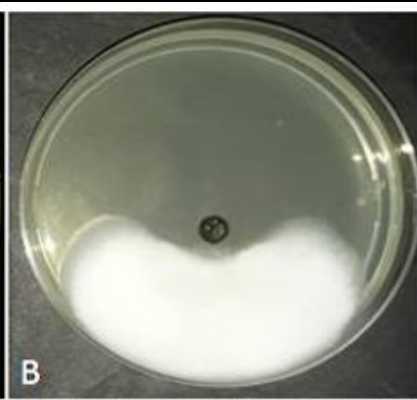

Petroleum ether extract

N-hexane extract

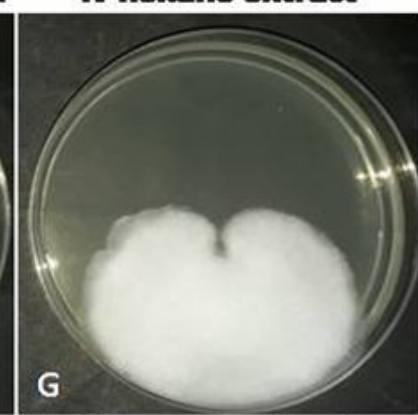

N-hexane extract

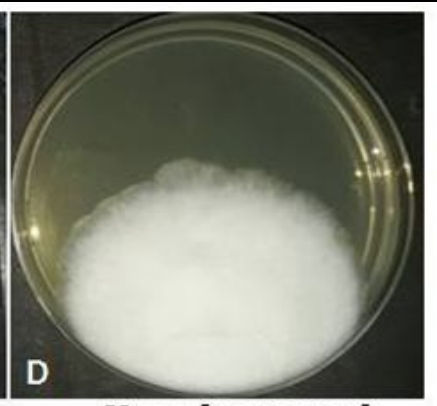

Negative control

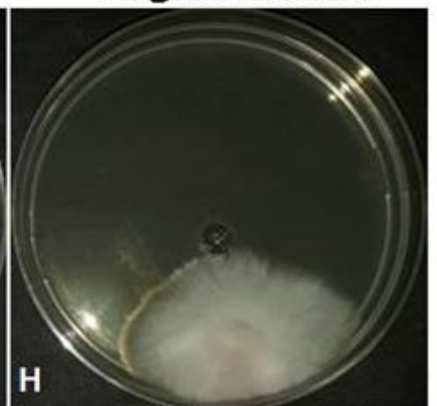

Positive control

Figure 4: Growth-retarding activity of tulsi extracts (100\%) against Fusarium oxysporum. (A), (B), (C) O. gratissimum; (E), (F), (G) O. basilicum; (D) DMSO negative control; (H) Cyclohexamide positive control. 


\subsection{Antifungal activities of Ocimum extract}

Extract of four different solvent systems were tested against two fungal plant-pathogens, viz., Fusarium oxysporum and $F$. solani, by recording the zone of inhibition after $72 \mathrm{~h}$. The presence or absence of the zone of inhibition indicated susceptibility or resistance, respectively, of the particular fungal pathogen against the specific solvent extract. The antifungal activity of $O$. sanctum and $O$. gratissimum were studied and the activities of their extracts at $100 \%$ concentration are shown in Figure 4.

Similar to the bacterial assay, the antifungal activity of the four solvent-extracts of both the tulsi species followed an increasing trend with increased concentrations; the highest activity was found at the highest concentration (100\%). Pattern of inhibition zones was almost similar for all the cases irrespective of solvents and concentrations. However, the diameter of the inhibition zones was always the highest with positive control and no inhibition zone was found in negative control.
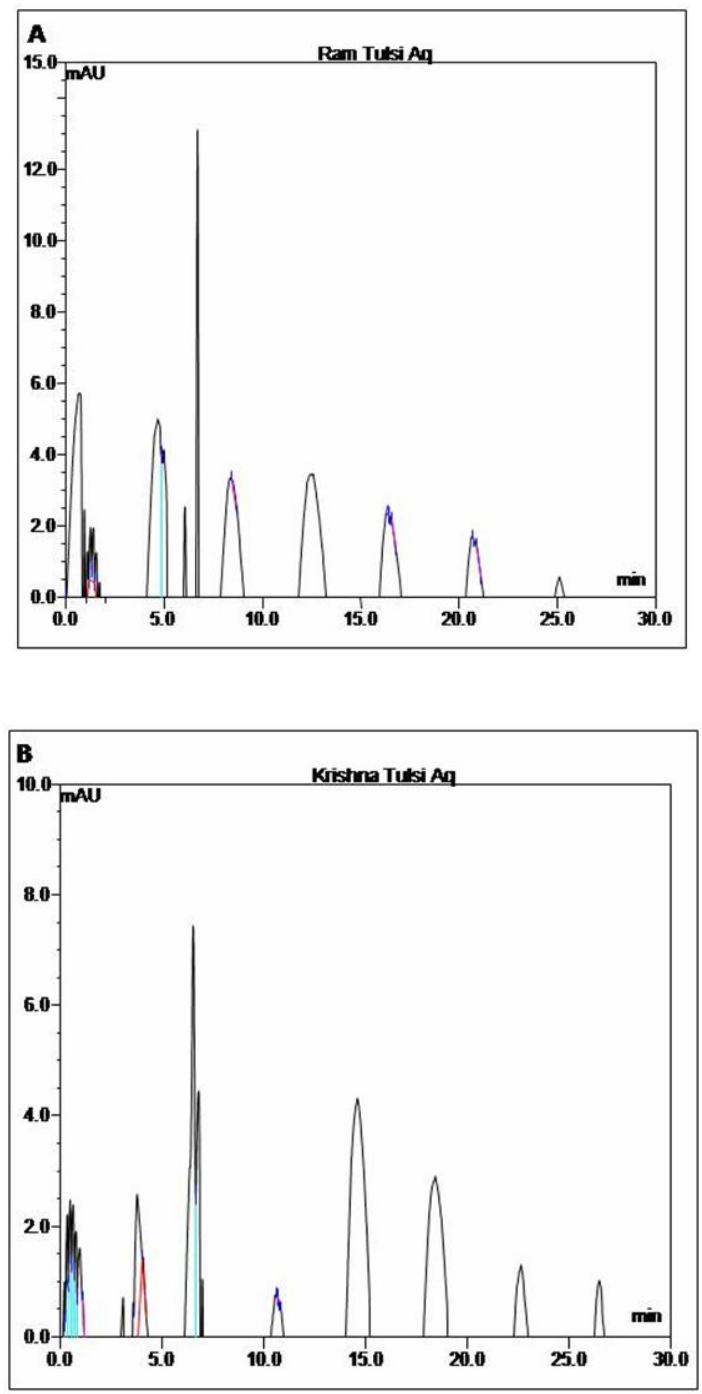

Figure 5: HPLC chromatograms of crude aqueous extracts of (A) O. gratissimum and (B) O. sanctum.
Irrelevant to the solvent systems and extract concentrations used, the $O$. gratissimum showed relatively higher antifungal activity showing larger zones of inhibition. Again, compared to $F$. solani, $F$. oxysporum showed higher susceptibility to the extracts of both the tulsi species showing smaller zones of inhibition. The same was applicable for all the four extract concentrations and the solvents. We did not see any significant qualitative differences in the antifungal activities among the three solvent systems used.

The antifungal activities of the tulsi extracts depended on the solvent used for extraction and the extract's concentration. Relatively stronger inhibition was observed in $F$. oxysporum than in $F$. solani. The inhibition was independent of the solvent system used. It was also clear that $O$. gratissimum had stronger antifungal property than $O$. sanctum.

\subsection{HPLC fingerprinting of crude Ocimum extracts}

The HPLC chromatograms of the Ocimum extracts are presented in the Figure 5. In methanol extract of $O$. sanctum and $O$. gratissimum, the HPLC chromatograms gave 171 peaks and 145 peaks, respectively. After background-deduction, 3 major peaks remained in methanolic extract of $O$. sanctum at retention time (RT) of 3.37-7.72 mins and 12 peaks in $O$. gratissimum at RT of 3.84-12.21 min. Similarly, after background-deduction, $\mathrm{n}$-hexane extract revealed presence of 3 major peaks in $O$. sanctum at RT of $0.640-20.73$ min and 2 peaks in $O$. gratissimum at RT of 5.58-6.03 min. Meanwhile, chromatograms of the aqueous extract revealed the presence of 21 in $O$. sanctum at RT of 0.16-26.470 min and 23 peaks in O. gratissimum at RT of 0.720$25.117 \mathrm{~min}$

\section{Discussion}

\subsection{Ocimum extracts as antibacterial agent}

The highest concentration of plant extract showing the strongest antibacterial effect was nicely demonstrated by Bharathi et al. (2014) in Ocimum itself with methanol extracts. Shah et al. (2016) found that $O$. gratissimum had more phytochemicals and antibacterial properties compared to $O$. sanctum; in addition to the phytochemicals present in $O$. sanctum, $O$. gratissimum also had an additional compound, the saponins. They found that the methanolic extract was the most potent against bacteria compared to hexane, petroleum ether, water and ethanol. They tested antibacterial activities of tulsi against E. coli, Bacillus cereus, Staphylococcus aureus, Klebsiella pneumonia are, Aspergillus niger and Pencillium notatum. It could be hypothesized that the antibacterial compounds of tulsi were more dissolved in methanol compared to the other solvents. Saurabh and Komal (2017) while testing antimicrobial property of $O$. sanctum found that the methanolic extract was the most effective against $E$. coli. It should be noted that $O$. gratissimum is more vigorous and has stronger smell (B.K. Borah et al., unpublished results); therefore, it could also contain relatively higher amount of the antimicrobials. This hypothesis is strongly supported by the findings of Giri (2017); by GC analyses, they found that the eugenol content in the oil of $O$. gratissimum (47.45\%) was much higher than $O$. sanctum $(17.23 \%)$.

We found various levels of susceptibility of different bacterial species towards the same solvent extract of the same Ocimum species. In general, A. tumefaciens was the most susceptible species, while the E. coli was the least susceptible species. Various levels of antibacterial 
activity of tulsi essential oil were also reported earlier (Yamani et al., 2016; Kumar et al., 2018). A. tumefaciens is known to be susceptible to compounds present in many plants that are used for management of the tumor caused by it. While Berrada et al. (2013) recommended use of Coriaria myrtifolia extracts against A. tumefaciens, Bobbrala et al. (2009) found that organic extracts of as many as 44 different could be used against it.

Ratledge (1997) reported that the gram-negative bacteria are less susceptible to essential oil than gram-positive bacteria due to the presence of the outer membrane (Vaara, 1992). We found higher antibacterial activity of tulsi extract against gram-negative $A$. tumefaciens, but the other gram-negative bacteria (E. coli) showed the least effect in $O$. sanctum and gram-positive bacteria, $B$. megaterium, showed the least effect in $O$. gratissimum extracts. It is possible that because we screened only three bacterial species, and the results can not be possibly generalized; but it is also possible that $E$. coli, being an intestinal inhabitant, is frequently exposed to many drugs and chemicals and therefore, has attained resistance against common compounds present in tulsi extract. We need to test this hypothesis with more number of bacterial species.

The exact mechanism of the antimicrobial properties of Ocimum is not completely clear; nevertheless, multiple possible modes have been hypothesized. These include cell wall degradation, damage to cytoplasmic membrane resulting in leakage of cell contents, coagulation of cell cytoplasm, depletion of proton motive force (Bhattacharjya et al., 2019), inhibiting ATP production and inhibiting bacteria quorum sensing system (Aiemsaard et al., 2014; Luís et al., 2016). Earlier, Helander et al. (1998) found that the tulsi essentials oils, mostly the monoterpenes, causes deterioration of cytoplasmic membrane resulting in the expansion and high membrane fluidity. This leads to membrane-disordering and inhibition of the enzymes (Sikkema et al., 1995). This disruption of the cell causes leakage of potassium ions (Cox et al., 2000). Besides, tulsi essential oils are likely to exert their antibacterial effects by attacking more than one target in the bacterial cells. For example, their hydrophobicity enables them to sequester the membrane lipids, leading to leakage of cell contents (Burt, 2004).

\subsection{Ocimum extract against fungal species}

Variable activity of tulsi extracts on fungi is well-known. Mohr et al. (2017) reported significant antifungal effect of ethanol extract of $O$. gratissimum on F. oxysporum f. sp. lycopersici and $R$. solani. Earlier, Koba et al. (2009) found that the volatile oil of $O$. gratissimum contains thymol, a class of phenol that was probably responsible for antimicrobial properties. $O$. sanctum also showed weak antifungal activities against few fungi, due to the presence of geranyl acetate (Sethi et al., 2013). Later, Patil et al. (2017) found strong activity of methanol extract of $O$. sanctum against Candida albicans and Aspergillus niger; but only moderate activity against $A$. fumigatus and mild activity against Microsporum gypseum and Trichophyton rubrum. Filamentous fungi like F. solani, Penicillium funiculosum, Rhizomuco rtauricus and Trichoderma reesi are also variably susceptible to tulsi extract (Dharmagadda et al., 2005). Ethanol and methanol extracts of $O$. basilicum also possess antifungal properties (Kaya et al., 2008).
A previous study explained the antifungal activity of Ocimum by the composition of essential oils. The terpenes in tulsi, such as mono- and sesquiterpenes with aromatic rings and phenol groups, can form hydrogen bonds with the active sites of enzymes showing antimicrobial effects. Compounds such as alcohols, aldehydes, and esters too contribute to the antimicrobial activity of tulsi (Belletti et al., 2004). A subsequent study showed that the essential oils and active ingredients of $O$. sanctum exert antifungal activity by disrupting ergosterol biosynthesis and membrane integrity (Khan et al., 2010). Linalol, estragol, eugenol and methyl cinnamate have been reported as the principal antifungal ingredients of tulsi (Reuveni et al., 1984). While some reports estragol as the major growth inhibitant of Aspergillus niger, A. ochraceus, and Fusarium culmorum (Ozkan and Erkmen, 2001), others report that the combination of linalol and estragol are more effective against Rhizopus nigricansi (Alpsoy, 2010). On the other hand, eugenol better inhibited growth of Fusarium oxysporum compared to linalool and estragol (Kocic-Tanackov et al., 2011)

\subsection{HPLC fingerprints of Ocimum extracts}

There have been several reports of HPLC fingerprinting of tulsi. Das et al. (2017) reported presence of 11 compounds in dark and 9 compounds in bright $O$. sanctum. Deo et al. (2011) developed an HPLC chromatograph in reversed phase column with detection at $254 \mathrm{~nm}$, where methanol could resolve 10 and 11 peaks in $O$. sanctum and $O$. kilimandsacharicum, respectively. However, they gave only 3 and 2 major, respectively, in aqueous extracts. We found different HPLC fingerprints of $O$. sanctum and $O$. gratissimum which obviously indicate the presence of different compounds and/ or their varied relative amounts in different tulsi species.

HPLC profile of the tulsi extracts showing significant antimicrobial activity can be used to identify tulsi species. Presence of similar peaks may indicate presence of the same compound (to different levels); and presence of different peaks may indicate presence of different compounds. Same RTs or RTs with minor difference indicate the presence of same metabolites. Similar conclusions were drawn before when Shanaida et al. (2017) detected various amino acids: aspartic acid, asparagine, serine, arginine, alanine, proline and isoleucine in O. americanum seeds. Shafqatullah et al. (2014) detected 10 compounds in ethanolic extracts of $O$. sanctum; three were identified as gallic acid, chloroganic acid and vanillic acid. HPLC with respect to RTs can also be taken as references to identify the compound; such differences might correlate with the observed difference in their antimicrobial activities. Higher number of peaks in the aqueous extracts could indicate the presence of primary metabolite(s) along with the secondary ones in the extracts. The phytochemicals in the extracts of Ocimum might act alone or in combination in exerting their growth inhibition activity against bacteria and fungi. In our study, although both the Ocimum showed antimicrobial activities, the levels of activity, depended on: (i) the microbial species (ii) the solvent, (iii) the extract concentration and, (iv) the tulsi species. Correlating to this result, the two species also showed different HPLC-profiles.

\section{Conclusion}

Plants are still important source of medicines since the first commercial natural product, morphine, was introduced by Merck in 1826. More than $80 \%$ of the population in the developing world still depends on plants as source of medicines. Usage of majority of the 
plant-derived drugs is attributed to their ethnopharmacological applications. Tulsi being an ethnically important medicinal plant, it is essential to understand its useful properties and their modes of action for purposing and repurposing its compounds. Although, further research will be needed for realization of the plant's complete array of potentials, we believe that our work will pave a way in this direction.

\section{Acknowledgements}

NR is grateful to DBT, Govt. of India for studentship. NR thanks P.K. Nath, M. Gogoi, G.M. Baldodiya and G. Baruah for technical help. Funds received from DBT, DST and ICAR were partly used in this study.

\section{Conflict of interest}

The authors declare no conflicts of interest relevant to this article.

\section{References}

Aiemsaard, J.; Aiumlamai, S.; Aromdee, C.; Taweechaisupapong, S. and Khunkitti, W. (2011). The effects of lemongrass oil and its major components on clinical isolate mastitis pathogens and their mechanisms of action on Stapylococcus aureus DMST 4745. Res. Vet. Sci., 91(3): e31-e37.

Alpsoy, L. (2010). Inhibitory effect of essential oil on aflatoxin activities Afr. J. Biotechnol., 9(17):2474-2481.

Amadi, J.E.; Salami, S.O. and Eze, C.S. (2010). Antifungal properties and phytochemical screening of extracts of African Basil (Ocimum gratissimum L.) Agric. Biol. J. N. Am., 1(2):163-166.

Atal, C.K. and Kapur, B.M. (1989). Cultivation and utilization of medicinal plants. 1st Ed., Regional Research Laboratory, Council of Scientific and Industrial Research, Jammu-Tawi.

Bansavatar, C.S.; Kurup, R. and Ansari, A.A. (2015). Antimicrobial properties of Ocimum sanctum and Calotropis gigantean leaves. Br. Microbiol. Res. J., 8(4):532-539.

Bauer, A.W.; Kirby, W.M.; Sherris, J.C. and Turck, M. (1966). Antibiotic susceptibility testing by a standardized single disk method. Am. J. Clin. Pathol., 45(4):493-496.

Belletti, N.; Ndagijimana, M.; Sisto, C.; Guerzoni, M.E.; Lanciotti, R. and Gardini, F. (2004). Evaluation of the antimicrobial activity of citrus essences on Saccharomyces cerevisiae. J. Agric. Food Chem., 52(23):69326938.

Berrada, H.; Farah, A.; Fadil, M. and Benbrahim, K.F. (2013). Antibacterial activity of Coriaria myrtifolia against Agrobacterium tumefaciens: Plant pathogen responsible for crown gall. Afr. J. Microbiol. Res., 7(48):5529-5532.

Bharathi, T.; Kolanjinathan, K. and Saranraj, P. (2014). Antimicrobial activity of solvent extracts of Ocimum sanctum, Azadirachta indica and Phyllanthus amarus against clinical pathogens. Glob. J. Pharm., 8(3):294-305

Bhattacharjya, D.; Adhikari, S.; Biswas, A.; Bhuimali, A.; Ghosh, P. and Saha, S. (2019). Ocimum phytochemicals and their potential impact on human health. In: Phytochemicals in Human Health, Vol. 1. (ed. Rao, V., Dennis, M. and Rao, L.) Intech. Open, Doi: 10.5772/intechopen, pp: 88555 .

Bobbrala, V.; Rao, G.S.; Maduri, D.B. and Naidu, K.C. (2009). Biocide potentialities of different plant methanolic extracts against crown gall bacteria, viz., Agrobacterium tumefaciens. Biomed. Pharm. J., 2(1):79-84.
Burt, S. (2004). Essential oils: Their antibacterial properties and potential applications in foods: A review. Int. J. Food Microbiol., 94(3):22353.

Cox, S.D.; Mann, C.M.; Markham, J.L.; Bell, H.C.; Gustafson, J.E.; Warmington, J.R. and Wyllie, S.G. (2000). Mode of antimicrobial action of essential action of essential oil of Melaleuca alternifolia tea tree oil. J. Appl. Microbiol., 88(1):170-175.

Darrah, H. (1974). Investigations of the cultivars of basils (Ocimum). Econ. Bot., 28(1):63-67.

Das, M.K.; Mandal, M. and Mandal, S. (2017). Broad antibacterial spectrum and high performance liquid chromatography profiles of Ocimum sanctum leaf extract. Acta Sci. Pharm. Sci., 1(6):2-7.

Deo, S.S.; Inam, F. and Mahashabde, R.P. (2011). Antimicrobial activity and HPLC fingerprinting of crude Ocimum extracts. E J. Chem., 8 (3): 1430-1437.

Dharmagadda, V.S.S.; Tandon, M. and Vasudevan, P. (2005). Biocidal activity of the essential oils of Lantana camara, Ocimum sanctum and Tagete spatula. J. Sci. Ind. Res., 64(1):53-56.

Fabricant, D.S. and Farnsworth, N.R. (2001). The value of plants used in traditional medicine for drug discovery. Env. Health Pers., 109(1): $69-75$.

Fuster, J.; Negro, S.; Salama, A.; Fernandez-Carballido, A.; Marcianes, P.; Boeva, L. and Barcia, E (2015). HPLC-UV method development and validation for the quantification of ropinirole in new PLGA multiparticulate systems: Microspheres and nanoparticles. Int. J. Pharm., 491(1): 310-317.

Gautam, M.K. and Goel, R.K. (2014). Toxicological study of Ocimum sanctum Linn. leaves: Hematological, biochemical, and histopathological studies. J. Toxicol., 135654. doi: 10.1155/2014/135654

Giri, P. (2017). Morphological and pytochemical analysis of Ocimum gratissimum Linn. A potential source of natural eugenol. Int. J. Pharma. Bio. Sci., 8(2):415-423.

Helander, I.M.; Alakomi, H.-L.; Latva-Kala, K.; Mattila-Sandholm, T.; Pol, I.; Smid, E.J.; Gorris, L.G.M. and Wright, A.V. (1998). Characterization of the action of selected essential oil components gram-negative bacteria. J. Agric. Food Chem., 46(9):3590-3595.

ICH, International Conference on Harmonisation (2005). Technical requirements for registration of pharmaceuticals for human use. Quality Guideline: All quality guidelines, analytical validation Q2. Q2 (R1) - validation of analytical procedures: text and methodology, Geneva.

Jamshidi, N. and Cohen, M.M. (2017). The clinical efficacy and safety of tulsi in humans: a systematic review of the literature. Evid.-Based Complementary Altern. Med., 17(1):1-13; Article ID 9217567, https://doi.org/10.1155/2017/9217567.

Kadian, R. and Parle, M. (2012). Therapeutic potential and phytopharmacology of tulsi. Int. J. Pharm. Life Sci., 3(7):1858-1867.

Kalita, J. and Khan, M.L. (2013). Commercial potentialities of essential oil of Ocimum members growing in North East India. Int. J. Pharm. Biol., 4(4):2559-2564.

Kaya, I.; Yigi, N. and Benli, M. (2008). Antimicrobial activity of various extracts of Ocimum basilicum L. and observation of the inhibition effect on bacterial cells by use of scanning electron microscopy. Afr. J. Trad. Compl. Alt. Med., 5(4):363-369.

Khan, A.; Ahmad, A.; Akhtar, F.; Yousuf, S.; Xess, I.; Khan, L.A. and Manzoor, N. (2010). Ocimum sanctum essential oil and its active principles exert their antifungal activity by disrupting ergosterol biosynthesis and membrane integrity. Res. Microbiol., 161(10):816-823. 
Koba, K.; Poutouli, P.W.; Raynaud, C. and Sanda, K. (2009). Antifungal Activity of the essential oils from Ocimum gratissimum L. Grown in Togo. J. Sci. Res., 1(1):164-171.

Kocic-Tanackov, S.; Dimic, G.; Levic, J. and Tanackov, I. (2011). Antifungal activities of basil (Ocimum basilicum L.) extract on Fusarium species. Afr. J. Biotechnol., 10(50):10188-10195.

Kumar, V.; Chakraborty, A.; Kaur, M.; Pandey, S. and Jena, M.K. (2018). Comparative study on antimicrobial activity of tulsi (Ocimum sanctum) and neem (Azadirachta indica) methanol extract. Asian J. Pharm. Clin. Res., 11(12):514-517.

Luis, A.; Duarte, A.; Gominho, J.; Domingues, F. and Duarte, A.P. (2016). Chemical composition, antioxidant, antibacterial and anti-quorum sensing activity of Eucalyptus globulus and Eucalyptus radiata essential oil. Ind. Crop. Prod., 79(1): 274-282; doi: 10.1016/j/indcrop.2015. 10.055 .

Mohr, F.B.M.; Lermen, C.; Gazim, Z.C.; Gonçalves, J.E. and Alberton, O. (2017). Antifungal activity, yield, and composition of Ocimum gratissimum essential oil. Genet. Mol. Res., 16(1):1-10; doi: 10.4238/ gmr16019542. PMID: 28362991.

Ozkan, M. and Erkmen, O. (2001). Antimicrobial activity of the essential oils of Turkish plant spices. Eur. Food Res. Technol., 212(6):658-660.

Patil, R.C.; Kulkarni, C.P. and Pandey, A. (2017). Antifungal and phytochemical properties of Tinospora cordifolia, Azadirachta indica and Ocimum sanctum leaves extract. J. Med. Plants Stud., 5(5):23-26.

Ratledge, C. (1997). Microbial lipids, in microbial lipids, Vol. 1. Rehm H.J. and Reed, G. (eds.) Academic Press, London, pp:3-22.

Reuveni, R.; Fleisher, A. and Putievsky, E. (1984). Fungistatic activity of essential oils from Ocimum basilicum chemotypes. Phytopath. 110(1):2022.

Sajjadi, S.E. (2006). Analysis of the essential oils of two cultivated basil (Ocimum basilicum L.) from Iran. DARU J. Pharm. Sci., 14(3): 128-130.
Saurabh, G. and Komal, S. (2017). Comparative characterization for antimicrobial activity and bioactive compounds present in leaf extract of Ocimum sanctum. J. Food Ind. Microbiol., 3(1):120. doi: $10.4172 / 2572-4134.10001$.

Sethi, S.; Prakash, O.; Chandra, M.; Punetha, H. and Pant, A.K. (2013). Antifungal activity of essential oils of some Ocimum species collected from different locations of Uttarakhand. Ind. J. Nat. Prod. Res., 4(4): 392-397.

Shafqatullah; Khan, R.; Hassan, W.; Hussain, A.; Asadullah; Rehman, K. and Ali, J. (2014). Development of HPLC method by UV-VIS detection for the quantification of phenolic acids in different Ocimum sanctum Linn. extracts. Pak. J. Pharm. Sci., 27(5):1271-1275.

Shah, S.N.; Murugan, M.; Gopukumar, S.T. and Praseetha, P.K. (2016). A comparative study of two selected Ocimum species with relevance to phytochemical, antimicrobial and molecular isolation. Res. J. Pharm. Biol. Chem., 8(3):1014-1020.

Shanaida, M.; Kernychna, I. and Shanaida, Y. (2017). Chromatographic analysis of organic acids, amino acids, and sugars in Ocimum americanum L. Acta Pol. Pharm. Drug Res., 74(2):729-734.

Sikkema, J.; de Bont, J.A. and Poolman, B. (1995). Mechanism of membrane toxicity of hydrocarbons. Microbiol. Rev., 59(2):201-222.

Singh, N. and Kumar, D. (2010). Variability, heritability and genetic advance in tulsi (Ocimum sanctum L.). Asian Sci., 5(2):89-92.

Tantry, B.A., Avneesh, K., Shiak, R. and Tantry, M.N. (2016). Antibacterial evaluation and phytochemical screening of methanolic extract of Ocimum sanctum against some common microbial pathogens. Glob. Adv. Res. J. Microbiol., 5(1):10-15.

Vaara, M. (1992). Agents that increase the permeability of the outer membrane. Microbiol. Rev., 56(3):395-411.

Yamani, H.A.; Pang, E.C.; Mantri, N. and Deighton, M.A. (2016). Antimicrobial activity of tulsi (Ocimum tenuiflorum) essential oil and their major constituents against three species of bacteria. Front. Microbiol., 7(7):681, doi: 10.3389/fmicb.2016.00681. eCollection 2016. 